\title{
Metrical conditioning of word-final devoicing in Polish
}

\author{
Uwarunkowania metryczne ubezdźwięcznienia obstruentów \\ wygłosowych w języku polskim \\ Tomasz CISZEWSKI ${ }^{1}$ \\ University of Gdańsk
}

\begin{abstract}
The present paper investigates a segmental phenomenon traditionally referred to as word-final obstruent devoicing in Polish. It is generally assumed that the context in which it applies is solely related to the absolute word-final position before silence. By inference, full voicing of a wordfinal obstruent is retained only when (i) it is followed by a voiced segment (a vowel or a consonant) in an utterance or when (ii) it is appended with a suffix which begins with a vowel. In this research a different group of factors which trigger the process is explored, namely the position of the obstruent within the metrical foot. If, as argued by Harris (2009), noninitial position within the foot is a typical lenition site (contrary to Iverson and Salmons 2007) and if devoicing is regarded as a special manifestation of lenition (through information loss, similarly to vowel reduction), a purely segmental (contextual) conditioning for voicing retention in obstruents word-finally cannot be maintained.
\end{abstract}

Keywords: Final obstruent devoicing, metrical theory of stress, prosody, word stress

\section{Streszczenie}

Niniejszy artykuł bada zjawisko segmentalne tradycyjnie określane w języku polskim jako wygłosowe ubezdźwięcznienie spółgłosek obstruentnych. Ogólnie przyjmuje się, że kontekst, w którym ma zastosowanie, jest wyłącznie związany z bezwzględną ostateczną wygłosową pozycją słowa przed ciszą. W związku z tym, pełna dźwięczność na końcu słowa jest zachowywana tylko wtedy, gdy (i) po nim następuje segment dźwięczny (samogłoska lub

1 (D) https://orcid.org/0000-0003-0259-2276. 
spółgłoska) lub gdy (ii) jest dołączana z przyrostkiem rozpoczynającym się od samogłoski. W przedstawionym artykule badana jest inna grupa czynników, które wyzwalają ten proces, a mianowicie pozycja w stopie metrycznej. Jeśli, jak argumentował Harris (2009), nieinicjalna pozycja w stopie jest typowym miejscem osłabienia (w przeciwieństwie do Iverson i Salmons 2007) i jeśli ubezdźwięcznienie jest uważany za specjalny przejaw osłabienia (poprzez utratę informacji, podobnie jak redukcja samogłosek), nie można utrzymać czysto segmentowego (kontekstowego) uwarunkowania wyrażania retencji głośności w pozostałych kontekstach.

Słowa kluczowe: wygłosowe ubezdźwięcznienie spółgłosek obstruentnych, teoria reprezentacji metrycznej akcentu, prozodia, akcent wyrazowy

\section{Introduction}

The present paper investigates a segmental phenomenon traditionally referred to as word-final obstruent devoicing in Polish. It is generally assumed that the context in which it applies is solely related to the absolute word-final position before silence. By inference, full voicing of a word-final obstruent is retained only when (i) it is followed by a voiced segment (a vowel or a consonant) in an utterance or when (ii) it is appended with a suffix which begins with a vowel.

In this research a different group of factors which trigger the process is explored, namely the position of the obstruent within the metrical foot. If, as argued by Harris (2009), non-initial position within the foot is a typical lenition site (contrary to Iverson and Salmons 2007) and if devoicing is regarded as a special manifestation of lenition (through information loss, similarly to vowel reduction), a purely segmental (contextual) conditioning for voicing retention in obstruents word-finally cannot be maintained.

The major assumption of the researchis illustrated in (1) below. The voiced realizations in (1a) are found in word/preposition-final but footinitial position, whereas the voiceless ones occur in the segmentally identical context but foot-internally within a trochaic (Strong-weak) or a dactylic (Strong-weak-weak) foot (1b).

$\begin{array}{ll}\text { (1) a. Voiced (foot-initial): } & \text { b. Voiceless (foot-internal): } \\ \text { pod obraz po\{dobraz\} } & \text { pod obrazem \{poto\}\{brazem\} } \\ \text { under the picture (accusative, sg.) } & \text { under the picture (instrumental, sg.) } \\ \text { przez okno prze\{zokno\} } & \text { przezokienko \{przeso\}\{kienko\} } \\ \text { through the window (accusative, sg.) } & \text { through the window (dimunitive, sg.) } \\ \text { przed oknem prze\{doknem\} } & \text { przed oknami \{przetok\}\{nami\} } \\ \text { in front of the window (instrumental, sg.) } & \begin{array}{l}\text { in front of the windows (instrumental, pl.) } \\ \text { sąd orzekł są\{dozekw\} }\end{array} \\ & \text { sąd ustalif \{satu\}\{stalił\} }\end{array}$


the court established

pięć \{metrufot\}\{swupka\}

pięć metrów od słupka

five meters from the goalpost

We expect that the generally accepted view that obstruent devoicing in Polish is merely a word-final (pre-pausal) phenomenon will have to modified and re-defined in terms of metrical phonology.

According to this hypothesis, variability is predicted in the voicing of the obstruent in the context where it is followed by a full well-formed foot carrying secondary stress whose first syllable begins with a vowel, or more generally with a voiced segment (2).

(2) przez ambulatorium

through the out-patients ward

przed barykadą

in front of the barricade

sąd uniewinnił

the court acquitted prze $\{\mathbf{s}$ ?zambula\}\{torium $\}$

prze $\{\mathbf{t}$ ?dbari $\}\{k a d o \tilde{}\}$

są\{t?dunie\}\{vinnił\}

These predictions may be tested by analysing acoustically the recordings of a specially designed corpusand by conducting perception tests whose aim is to elicit the most robust acoustic cues of voicing perception.

If the proposed phonological predictions are correct, we should observe different degrees of devoicing depending on the metrical position as well as other regularities typical for the intervocalic relations which hold between the vowels in the foot-internal context, e.g. variation in pitch slopeas well asthe intervocalic durational and tonal dependencies.

The zero hypothesis assumes that the voicing of word-final obstruents in Polish relies merely on the pre-pausal vs. prevocalic (or more generally prevoiced) context, which triggers complete devoicing or maintains full voicing of the obstruent, respectively.

According to the alternative hypothesis, the variability in obstruent voicing in Polish is conditioned by the prosody of an utterance in which the obstruent occurs.

The following research questions are formulated:

- is the pre-pausal devoicing complete?

- is the intervocalic voicing complete? 
- do the vowels belonging to the putative foot display the same durational and tonal differences across word boundaries as wordinternal feet?

- is the obstruent voicing related to the degree of stress (primary vs. secondary) on the foot in which it occurs?

- what are the acoustic features of pre-pausal (word-final) obstruents?

- what are the acoustic features of pre-vocalic (word-final but footinternal) obstruents?

- what are the most robust cues to the perception of obstruent voicing?

The aim of the research is to reject $\mathrm{HO}$ by showing that it is the metrical structure which isboth the trigger and the locus of various phonological regularities, one of which is consonantal voicing.

The results of the project may also lead to re-analyses of devoicing in languages other than Polish.

\section{The state of the art: an overview}

Word-final obstruent devoicing has been taken up in both phonological and phonetic/acoustic literature with respect to many languages, e.g. German (Brockhaus 1995), Russian (Dmitrieva, Jongman and Sereno 2010), Lithuanian (Campos-Astorkiza 2006), Dutch (Grijzenhout 2000), Afrikaans (Coetzee et al. 2016), Turkish (Kopkalli 1993), Persian (Tofigh and Abolhasanizadeh 2015) and Setswana (Boyer and Zsiga 2013), among others. A detailed overview ofobstruent voicing options has been provided in Ashby and Maidment (2005). As far as the positional (lexical and syllabic) conditioning for the phenomenon is concerned, a distinction has also been postulated between languages in which the devoicing affects word-final obstruents, e.g. Russian, Uyghur, and languages in which the devoicing affects syllable-final obstruents, e.g. Breton, Malay (Myers 2012).

In the phonological literature the process has been analysed from various theoretical standpoints: Optimality Theory (van Oostendorp, 2008, Kawahara and Garvey 2010), Government Phonology (Schwartz 2010) or Natural Phonology (Dressler 2009, Dziubalska-Kołaczyk 2006).

Sociolinguistic conditioning of obstruent devoicing has also been considered, e.g. Pooley (1994), whose analysis pertains to French working-class speakers.

An overview of the five leading journals in the field of acoustics/phonetics/phonology, i.e. TheJournal of the Acoustical Society 
of America, Journal of Phonetics, Phonetica, Language and Speech, Phonology, as well as some other internationally recognised journals, reveals that over the past three decades (1982-2018) the phenomenon of word-final obstruent devoicing has been taken up in over twenty research papers.

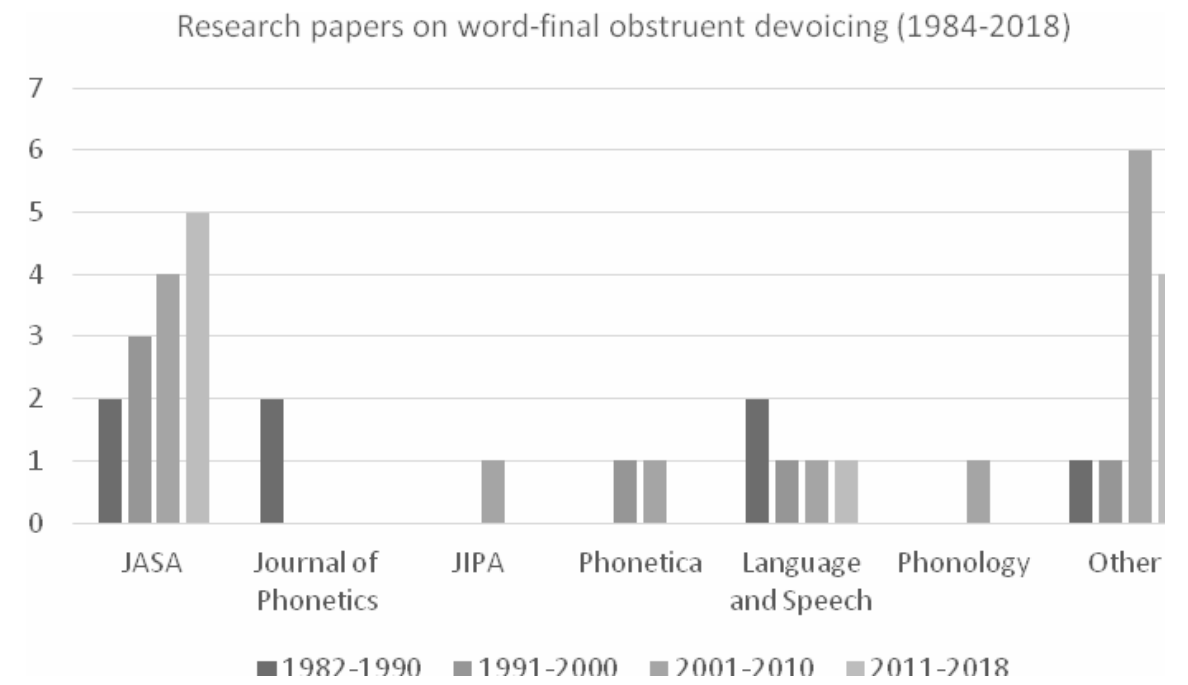

The relevant $J A S A$ publications on word-final devoicing include:

- Tieszen and Reed (1993), who show that regardless of the place of articulation of the plosive /p,b,t,d,k,g/ glottal pulsing increases in phonologically voiced plosives; they contrast their results with those obtained by Slowiaczek and Dinnsen (1985), who argue for complete neutralization in the same context,

- Walker, Southal and Hargrave (2017), who analyse duration, spectral energy and conclude that pre-pasual context favours correct word recognition,

- Dmitrieva (2014), who analyses the preceding vowel duration, the closure or frication duration, the duration of the release portion, and the duration of voicing during the obstruent closure, frication, and release,

- Campos-Astorkiza (2008), who shows that the differences in the closure duration and voicing during the closure are more robust cues for the obstruent voicing than the preceding vowel duration,

- Smith and Peterson (2011), who relate the degree of (de)voicing to the duration of the preceding vowel and the reduction of glottal pulsing in the obstruent closure phase in the context of ESL acquisition, 
- Dmitrieva (2005), who argues for incomplete neutralization of voicing in word-final position,

- Charles-Luce (1985), who claims that word-final stops in German are sensitive to the place of articulation, phonetic and sentential context, or even on individual lexical items,

- Whitehead and Metz (1982), who analyse the voicing of the intervocalic $/ \mathrm{h} /$ segment in non-words in deaf people,

- Matsui (2014), who discusses the perception of incompletely neutralised word-final stops in Russian,

- Sieczkowska and Dogil (2009), who take up the issue of obstruent devoicing in sonorant clusters in German and Polish,

- Myers (2009), who address the issue of obstruent devoicing in the utterance-final position vs. phrase-medial position preceding a vowel, a nasal, a voiced obstruent, or a voiceless obstruent,

- Gonzalez (2001), who analyses spirantisation of word-final /b,d,g/ in Spanish in stressed and stressless syllables,

- Coetzee et al. (2016), who investigate obstruent devoicing in different positions in the word and

- Fulop (1993), who discusses the issue of formant clarity and the intensity of sonorants before word-final underlyingly voiced obstruents.

The Journal of the International Phonetic Association (JIPA) offers only onepublication pertaining directly toobstruent devoicing, i.e. González (2002). In the Journal of Phonetics the topic of word-final obstruent devoicing has been taken up in the following papers:

- Slowiaczek and Dinnsen (1985), who argue for incomplete nautralisation ofvoiced vs. devoiced obstruents in the word-final position in Polish, and

- Slowiaczek and Szymanska (1989), who analyse the perception of the voiced/devoiced contrast word finally in Polish on the basis of acoustic cues.

In Phonetica the two relevant papers are:

- Abdelli-Beruh (2004), who discuss the duration of devoiced stops in French, and

- Blumstein (1991), who argues for complete nautralisation of the word-final voiced and devoiced stops in Polish, German and Catalan.

Language and Speech provides analyses of word-final devoicing with a strong phonological bias, i.e. 
- Smith (2002), who argues that prosodic finality is marked by sentence final vowel duration,

- Kaplan (2011), who concludes that lenition of intervocalic voiced stops yields spirants rather than voiceless stops due to the perceptual salience of the latter,

- Barry (1984), who undertakes the problem of whether the voicing information is an integral part of the perceptual unit,

- Jongman et al. (1992), who conducted a perceptual experiment pertaining to the relation between the underlying voicing of an obstruent and the duration of the preceding vowel,

and

- Lisker (1986), who proposes as many as 16 pattern properties which play a role in determining whether the listener reports hearing a voiced or a voiceless stop.

In Phonology the phenomenon of word-final devoicing has been discussed by Iverson and Salmons, (2007), who analyse word-final devoicing as lenition in Dutch and fortition in German within the framework of Evolutionary Phonology (Blevins 2004).

Other publications on word-final obstruent devoicing include (the list is by no means exhaustive, but aims at pointing at the typical research bias in the field):

- James (1987), who argues for prosodic (metrical) foundations of segmental phenomena,

- Rubach (1996), who proposes that prepositions do not form a prosodic word of their own (and thus cannot undergo prosodic word-final devoicing),

- Strycharczuk (2012), who argues that word-final sonorants block final devoicing as well as voicing assimilation,

- Wetzels and Mascaró (2001), who claim that [voice] is a privative feature and that word-internal devoicing can occur in a language without wordfinal devoicing,

- Padgett (2012), who provides an OT analysis of prosodically conditioned word-final devoicing in Russian,

- Padgett (2015), who claims that obstruent devoicing is an utterance-final (rather than word-final) phenomenon and 
- Schwartz (2012), who analyses the voicing of word-final obstruents preceding a word-initial vowel in an utterance.

The research scope of the above papers is thus fairly diversified and includes the following approaches: acoustic, perceptual, phonological, semantic and prosodic.

\section{Research bias in papers on word-final obstruent devoicing (1982-2018)}

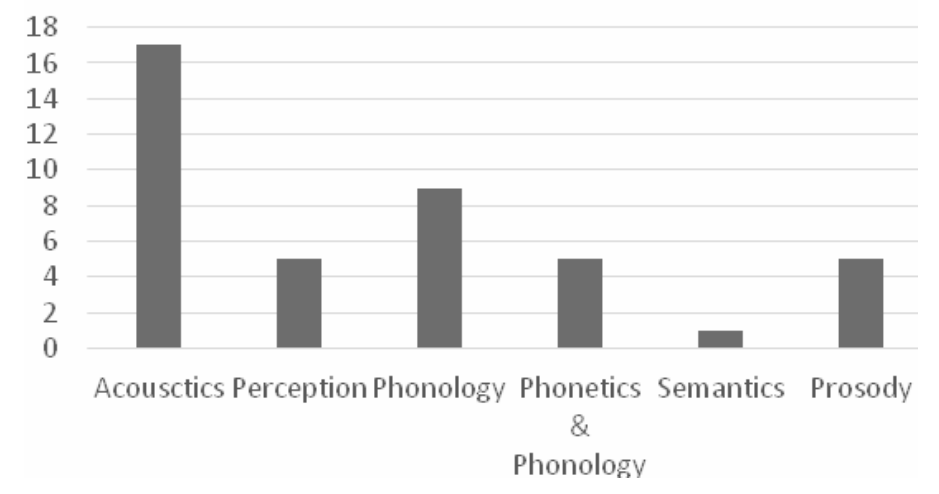

The above overview of the relevant literature, however, reveals that little research attentionhas been paid to the prosodic (metrical) conditioning of the phenomenon and, what has been conspicuously underrepresented in the literature, the attempts of employing acoustic and perceptual data in constructing a phonological model which can successfully cater for the voicing of Polish word-final obstruents occurring in different metrical positions.

The available metrically-oriented analyses are scarce and pertain to phonological, rather than acoustic aspects of word-final devoicing. Polish (which is one of the frequently referred to languages) is heavily underrepresented in the literature, though.

\section{Specific research goals and expected results}

The work plan for the project is divided into three major phases which correspond to the specific tasks related to (i) the preparation of the production database and recordings, (ii) the preparation of the perception database and perception experiments and (iii) the preparation and online publication of the annotated POLVOICE database. 


\section{PHASE I: Production}

a. preparation of the corpus of utterances for recording. The corpus will comprise utterances which includecontent words and prepositions ending in underlyingly voiced obstruents placed in diversified metrical configurations:

- word-final before silence

- word-final before a vocalic suffix (=foot-internal position)

- word-final before an unstressed syllable in the following word (=footinternal position)

- word-final before a secondarily stressed syllable in the following word (foot-final position)

The complete Polish set of 10 obstruents will be used.

The corpus will be validated by a contracted specialist in Polish phonetics and phonology.

b. recording the corpus in a soundproof booth with a high-quality condenser microphone in the phonetic laboratory at the Faculty of Languages, University of Gdańsk (for Pomeranian and Kashubian speakers) and in the Acoustic-Phonetic Laboratory at the Institute of English, University of Silesia (Silesian and Lesser Poland speakers).

c. acoustic analysis and annotation of the recorded material in PRAAT

d. statistical analysis of the data

e. publication of the results and disseminating the research at selected international and domestic phonetic conferences.

\section{PHASE II: Perception}

a. extraction and manipulation of the target words including underlyingly voiced obstruents from the recorded material

b. preparation of the stimuli (target words in isolation and carrier phrases) for perception experiments

c. constructing the design for perception experiments

d. conducting the perception experiments

5e. statistical analysis of the collected data

6f. publication of the results and disseminating the research at selected international and domestic phonetic conferences

PHASE III: POLVOICE database compilation and online publication

a. preparation of annotated samples (including PRAAT textgrids and spreadsheets with numerical acoustic measurement data) 
b. compilation of detailed Informants' Profiles including biographical data

c. designing and creating the online version of the database

d. online publication of the POLVOICE database.

As shown in the literature review, the phenomenon of word-final obstruent devoicing in Polish has not as yet been given a multi-contextual acoustic treatment with a phonological (metrical) bias. The innovation in the present project consists in combining the acoustic data with the metrical position on which the obstruent occurs. We propose a research project which uniquely relates the operation of the process in its various acoustic manifestations to the phonological conditioning. This sort of approach is entirely absent in the available literature.

\section{Research Methodology}

The research methodology used in the project will be designed according to the state-of-the-art recording, measurement and speech analysis techniques as well as perception tests relevant to the hypotheses set forth in this study.

\section{Recording of the database and acoustic analysis}

- the database will be designed according to the various prosodic contexts in which voiced obstruents occur in both content words and in prepositions, i.e. (i) in isolation, (ii) utterance-finally, (iii) in utterance medial position before the following unstressed syllable and (iv) in utterance medial position before the following syllable carrying secondary stress. Prior to recording, the database will be appended with broad phonemic transcription.

- spectrally rich samples will be recorded in a soundproof booth with a high-quality condenser and dynamic microphones with a preamplifier. Additionally, a contact vibration microphone attached to the larynx area will be used in order to pick up skin vibration signals directly from vocal folds. The audio input and the glottal input will then be synchronized.

\section{Methods, techniques and tools}

The acoustic analysis will be conducted with PRAAT software. The measurements will include:

- consonant duration

- frication frequency for fricatives

- voice bar 
- frequency of the release burst for stops

- duration of the vowel preceding the obstruent

- duration of the vowel following the obstruent (for the foot non-initial context)

- intervocalic durational relations between the vowels flanking the obstruent (for the footnon-initial context)

- pitch slope of the vowel preceding the obstruent

- maximum F0 in vowels flanking the obstruent (for the foot non-initial context)

- difference between the maximum and mean F0 in vowels flanking the obstruent (for the foot non-initial context)

\section{Methods of results analysis}

- The numerical data will then be subject to statistical analysis in order to determine the statistical significance of particular acoustic parameters and the verify the hypothesised correlations between various parameters.

\section{Perceptual analysis}

The relevant samples will be extracted from the recorded database and resynthesized with PRAAT. The resynthesized stimuli will then be placed in the contexts of interest, i.e. in isolation, utterance-finally and in foot-medial position. The acoustic parameters will be artificially manipulated with a view to singling out the parameters which contribute to the informants' perception of voicing.

The categorical perception of voicing as well as theminimal perception threshold of partial voicing will be tested using the E-Prime software in the following tasks:

- identification tests: minimal pairs (existing words and nonwords)

- discrimination tests: same/different (AX and AXB patterns) with simultaneous measurement of reaction times in different inter-stimulus interval (short vs. long corresponding to phonetic vs. phonological processing, respectively)

- 'gating' tests: the aim is to check whether there exist robust acoustic clues to obstruent voicing in the qualities/quantities of the neighbouring vowels. In order to identify the clues successive portions of the target word will be presented to the informants. 
- Similarly to the treatment of the acoustic data, the numerical data obtained in perception experiments will then be subject to relevant statistical analyses.

\section{Compilation of the POLVOICE database}

The phonemic transcriptions of the database will be appended with allophonic transcriptions made on the basis of the acoustic analysis. Apart from the allophonic transcription of the material, the online version of the database will include:

- complete audio recordings

- numerical and statistical data

- metrical parsing of the utterances

- biographical information pertaining to informants' age, sex, educational and dialectal background.

\section{Conclusions and further research}

The present proposal does not only aim at the first comprehensive, multicontextual acoustic description of word-final obstruent devoicing in Polish but also opens the way for bridging the gap between the acoustics and the phonology of the process. In this sense it is a novel approach which contributes to the development of the apparently neglected research area and which will re-introduce the Polish language into the international discussion on obstruent voicing.

The present approach aims at providing a novel insight into the process of word-final obstruent devoicing in Polish which has not been sufficiently explored in the literature. The state-of-the-literature is rather dichotomic is the sense that it either concentrates on the acoustic data or pholnological generalisations but rarely employs the acoustic data into a phonological model. The present approach offers a unified description of the acoustics and the prosodic phonological underpinnings of the phenomenon.

\section{References}

Abdelli-Beruh, N. B. (2004). The Stop Voicing Contrast in French Sentences: Contextual Sensitivity of Vowel Duration, Closure Duration, Voiced Onset Time, Stop Release and Closure Voicing. Phonetica, 61, 201-219. 
Ashby, M. \& Maidment, J. (2005). Introducing Phonetic Science. Cambridge University.

Barry, W. J. (1984). Segment or Syllable? A Reaction-Time Investigation of Phonetic Processing. Language and Speech, 27(1), 1-15.

Blevins, J. (2004). Evolutionary Phonology: the emergence of sound patterns. Cambridge: Cambridge University Press.

Blumstein, S. E. (1991). The Relation between Phonetics and Phonology. Phonetica, 48, 108-119.

Brockhaus, W. (1995). Final devoicing in the phonology of German. Linguistische Arbeiten, 336. Max Niemeyer.

Campos-Astorkiza, R. (2006). Two sources of voicing neutralization in Lithuanian. Proceedings of ISCA Tutorial and Research Workshop on Experimental Linguistics, 28-30.

Campos-Astorkiza, R. (2008). A comparison between two cases of voicing neutralization: Final devoicing and voicing assimilation in obstruent clusters, The Journal of the Acoustical Society of America, 123, 3882.

Charles $\square$ Luce, J. (1985). Word $\square$ final devoicing in German and the effects of phonetic and sentential contexts. The Journal of the Acoustical Society of America, 77, S85. DOI: https://doi.org/10.1121/1.2022551.

Coetzee, A. W., Beddor, P. S., Bouavichith, D., Craft J. T. \& Wissing, D. (2016). F0 and plosivevoicing in Afrikaans. The Journal of the Acoustical Society of America, 140, 3106. DOI: https://doi.org/10.1121/1.4969697

Dmitrieva, O. (2005). Final devoicing in Russian: Acoustic evidence of incomplete neutralization. The Journal of the Acoustical Society of America, 117, 2570.

Dmitrieva, O. (2014). Final voicing and devoicing in American English. The Journal of the Acoustical Society of America, 136 (4), 2174.

Dmitrieva, O., Jongman, A. \& Sereno, J. (2010). Phonological neutralization by native and non-native speakers: The case of Russian final devoicing. Journal of Phonetics, 38/3, 483-492.

Dressler, W. U. (2009). Natural Phonology as part of natural linguistics. Poznań Studies in Contemporary Linguistics, 45(1), 33-42.

Fulop, S. A. (1993). Acoustic correlates of the fortis/lenis contrast in Swiss German plosives. The Journal of the Acoustical Society of America, 94, 1866.

Gonzalez, C. (2001). Stress effects on voicing and frication in voiced obstruents in north $\square$ central Spanish. The Journal of the Acoustical Society of America, 110, 27-37.

González, C. (2002). Phonetic variation in voiced obstruents in North-Central Peninsular Spanish. Journal of the International Phonetic Association, 32/1, 17-31.

Grijzenhout, J. (2000). Devoicing and voicing assimilation in German, English and Dutch: a case of constraint interaction. In Katarzyna Dziubalska-Kolaczyk (ed.), 
Trends in Linguistics. Studies and Monographs 134: Constraints and Preferences. Mouton de Gruyter, 201-228.

Harris, J. (2009). Why final obstruent devoicing is weakening? In Nasukawa, K \& P. Backley (eds.) Strength Relations in Phonology, Vol. 103 Studies in Generative Grammar, 9-45.

Iverson, G. K. \& Salmons J. C. (2007). Domains and directionality in the evolution of German final fortition. Phonology, 24, 121-145.

James, A. R. (1987). Prosodic structure in phonological acquisition. Second Language Research, 3:2, 118-140.

Jongman, A., Sereno, J. A., Raaijmakers, M. \& Lahiri, A. (1992). The Phonological Representation of [VOICE] in Speech Perception. Language and Speech, 35: 1-2, 137-152.

Kaplan, A. (2011). Perceptual Pressures on Lenition._Language and Speech, 54:3, 285-305.

Kawahara, S., \& Garvey, K. (2010). Testing the P-map hypothesis: Coda devoicing. Rutgers Optimality Archive, 1087.

Kopkalli, H. (1993). A Phonetic and Phonological Analysis of Final Devoicing in Turkish. PhD Thesis, University of Michigan.

Lisker, L. (1986). Voicing in English: A Catalogue of Acoustic Features Signaling /b/ Versus/p/ in Trochees, Language and Speech, vol. 29, 1, 3-11.

Matsui, M. (2014). On the gradience in perceptibility of word-final voicing contrast in Russian. The Journal of the Acoustical Society of America, 135, 22-26.

Myers, S. (2009). Perceptual studies of two phonological voicing patterns. The Journal of the Acoustical Society of America, 125, 2754.

Myers, S. (2012). Final devoicing: Production and perception studies. Prosody Matters: Essays in Honor of Elisabeth Selkirk, In Borowsky T., Kawahara, S. Shinya, T. \& Sugahara, M. (eds.) London, Equinox Publishing, 151-189.

van Oostendorp, M. (2008). Incomplete devoicing in formal phonology, Lingua, 118 (9), 1362-1374.

Padgett, J. (2012). The Role of Prosody in Russian Voicing Prosody Matters: Essays in Honor of Elisabeth Selkirk, In Borowsky T., Kawahara, S. Shinya, T. \& Sugahara, M. (eds.) London, Equinox Publishing, 181-207.

Padgett, J. (2015). Word-Edge Effects as Overphonologization of Phrase-Edge Effects. Proceedings of the 32nd West Coast Conference on Formal Linguistics. In Steindlet, U. et al. (eds.), Somerville, MA: Cascadilla Proceedings Project, 41-53.

Pooley, T. (1994). Word-final consonant devoicing in a variety of working-class French-a case of language contact? Journal of French Language Studies, 4(2), 215-233.

Rubach, J. (1996). Nonsyllabic analysis of voice assimilation in Polish. Linguistic Inquiry, 27, 69-110.

Schwartz, G. (2010). Phonology in the speech signal-unifying cue and prosodic licensing. Poznań Studies in Contemporary Linguistics, 46(4), 499-518. 
Schwartz, G. (2012). Initial glottalization and final devoicing in Polish English, Research in Language, 10, 159-172.

Sieczkowska, J. \& Dogil, G. (2009). Voicing Profile of Polish and German Sonorants in Obstruent Clusters. Proc. Mtgs. Acoust. 6, 062002.

Slowiaczek, L. \& Dinnsen, D., (1985). On the neutralizing status of Polish word-final devoicing. Journal of Phonetics, 13, 325-341.

Slowiaczek, L. \& Szymanska, H., (1989). Perception of word-final devoicing in Polish. Journal of Phonetics, 17, 205-212.

Smith, C. L. (2002). Prosodic Finality and Sentence Type in French. Language and Speech, 45:2, 141-178.

Smith, B. L. \& Peterson, E. A. (2012). Native English speakers learning German as a second language: Devoicing of word-final voiced stop targets J. Phonetics 40(1): 129-140. DOI: 10.1016/j.wocn.2011.09.004

Strycharczuk, P. (2012). Sonorant transparency and the complexity of voicing in Polish. Journal of Phonetics, 40(5), 655-671.

Tofigh, Z. and Abolhasanizadeh, V. (2015). Phonetic Neutralization: The Case of Persian Final Devoicing. Athens Journal of Philology, 123-134.

Tienszen, B. \& Reed, Ch. (1993). Final stop devoicing in Polish: Incomplete neutralization. The Journal of the Acoustical Society of America, 94, 18-66.

Walker, A., Southall, A., \& Hargrave, R., (2017). An acoustic and phonological description of/z/-devoicing in Southern American English, The Journal of the Acoustical Society of America, 142, 26-78.

Wetzels, W. L., \& Mascaró, J. (2001). The Typology of Voicing and Devoicing. Language, 77/2, 207-244.

Whitehead, R. L., \& Metz. D. E. (1982). The mechanics of abnormal laryngeal devoicing gestures exhibited by deaf persons. The Journal of the Acoustical Society of America, 71, S55. 
